\title{
殺菌刻の薬理学的研究技法
}

\author{
黄耿 堂, 山口勇 \\ 理化学研究所微生物薬理研究室 \\ （昭和 54 年 7 月 4 日受理）
}

\section{Advanced Methods for Toxicological Research on Agricultural Fungicide}

\author{
Keido Ko and Isamu YamaguchI \\ The Institute of Physical and Chemical Research, \\ Wako, Saitama 351, Japan
}

\section{は じめに}

殺菌剤の薬理研究は時代とともに移り変わり, その技 法も新しく導入され，改良されてきた.

戦前のボルドー液および石灰硫黄合剤の時代には形態 学的観察をおもな技法として研究が進められた. 戦後, 有機化学の進歩に伴い, 有機水銀剂をはじめ数種の重金 属を含む有機合成剂の開発が盛んな時代には, 開発され た薬剤のほとんどの作用中心元素は含有する重金属にあ ると思われ，エネルギー代謝系に及ぼす影響が注目され た. したがって, 細胞内の解糖系, TCA 回路, 電子伝 達系などを調べる一連の技法が盛んに行なわれた。 その 後, 1960年頃から, 農業用抗生物質が登場し, 呼吸系に 作用する薬剤が少なくなり, 研究者は生体成分の生合成 に対する薬剤の影響に目を向けた。このように，農薬用 殺菌剂の薬理研究は開発された新しい薬剤に応じて進ん できている。

しかしながら，これらの技法のほとんどは生化学およ び医薬の分野での毒物学の研究技法を模倣し, その技法 開発に依存してきた。たとえば，エネルギー代謝系の阻 害剂や蛋白合成系の阻害剂などの調べ方は単に農業用殺 菌剤を阻害㸞として用いるか, あるいは異なった病原菌 を材料にして，同じ反応系で実験を進めてきただけであ る. 最近になって, 農業用抗生物質ポリオキシンの誕生 で, 糸状菌特有の細胞壁合成阻害の実験系が試みられて きてから，農薬独自の技法がわずかながら感じられるよ うになった。
今までの薬理研究を振り返って見れば，その研究技法 は単純な試験管内の実験系で細胞内の代謝に及ぼす影響 と抗菌性を結びつけるだけのもので，生体上での防除薬 剂的機構とを結びつけることができるかどうかははなは だ疑問である. その上，これからの生化学的技法の共通 する条件として，薬剤は必ず in vitro でなんらかの形 で抗菌性を示すことが研究を進める上での大前提とされ ている.

しかるに，近年新しく開発された殺菌剤中には，培地 上で抗菌力がなく, 植物体上での浸透移行性が高く, 生 体上で著しく発病を抑制するものが圧倒的に多く見つか った.これら薬剤の作用機構について,一部の報告では, ファイトアレキシン誘発説が出されているが，この問題 の解決は薬理研究当面の重要課題の一つとして考えられ る.これらの研究課題を進める上で, 新しい農薬独自の 新技法が必然的に考案されなければならない. そこで， 筆者らは従来の技法を紹介し，合わせて今後これらの新 しい殺菌剤を研究するに当たり，考えうる技法について 触れてみたいと思う。

\section{I. 殺菌剤の薬理研究における生化学的技法}

殺菌剤の薬理学的研究を進めるに際し, 物理化学的性 質はもちろんのこと生物学的基礎知見をできる限り詳し く調べる必要がある. その最も重要な点は次のとおりで ある・

(1)できうる限り詳細な抗菌スペクトルを調べること 供試菌は病原菌, 非病原菌を問わず, とくに生化学的 
に基礎研究の進んでいる菌種は必ず入れること．さら に，検定培地は 1 種類だけでなく，天然，半合成，合成 などの培地を合わせて検討されるべきである，たとえ ば，イネいもち病防除薬剤であるオリゼメートは通常の ジャガイモ寒天培地では抗菌性を示さないが，ッァペッ ク寒天培地のような合成培地上では明らかに抗菌性を示 す例もある. 次に，培地の $\mathrm{pH}$ を数段階に分けて検定す ることも重要で，たとえば，カスガマイシンは $\mathrm{pH} 5$ の 培地ではじめて抗菌力を示すなどの例もある.

(2) 植物病理学的基礎見地をできうる限り詳細に検討 する

抗植物ウイルス性物質については省略するが，カビの 場合, 胞子の発芽, 発芽間の伸長, 附着器の形成, 侵入 菌系の植物体内への侵入, 組織内での菌系の生育状況, さらに, 組織中から, 分生子梗の形成, 胞子形成, 胞子 の飛散, 形成された胞子の病原性などの諸点について, 薬剂による作用を調べ，各段階における形態学的変化を 詳細に観察する。もちろん薬剤之菌の濃度関係につい ても重要な事項である. 細菌の場合には各種培養条件下 で，その増殖を薬剤がどのように，どの程度阻害するか を調べる，とくに，増殖を調べる際には，阻止円法や寒 天稀釈法だけでなく，振蕰培養した菌体懸濁液を比濁法 で調べる必要がある。

(3) 実験系の選択について

多くの病原菌の代謝およびその他の生化学的知見につ いては基礎的に研究が行なわれていない上に，実験系の 確立されたものは少ない。したがって，生化学的研究を 進めるには，生化学的に実験系が確立されたものを選ん ではじめたほうが種々な面で都合がよく，近道と思われ る。たとえば，細菌では大腸菌（E. coli)，糸状菌では アカパンかび (Neurospora crassa) が望ましい。しかし ながら，最終的な結論は該当病原菌を用いて立証すべき である，もちろん，薬剤によっては，選択性などの問題 で，上記のような菌種を用いることのできない場合もあ る.

以上述べた 3 点のほかに，多数注意すべき点がある が，これは本文中で必要に応じて述べたいと思う。

農業用殺菌剂を大きく分けると，エネルギー代謝系阻 害剂, 蛋白合成阻害剂, 核酸合成阻害剂, 細胞壁合成阻 害剂および脂質合成阻害剤になる。これらの阻害剤につ いておのおの代表例をあげて説明したい。

1）エネルギー代謝系阻害剤

前述のとおり，20年前の殺菌剂は水銀, 砒素, 錫, 銅な ぞ重金属を含む有機化合物が大半を占めていた．これら は多くの脱水素醭素を含む $\mathrm{SH}$ 醭素を阻害し，その作用
はシステイン，グルタチオンなど $\mathrm{SH}$ 化合物によって拮 抗されることが特徵とされている. その後, アンチマイ シン $\mathrm{A}$ (アンチピリキュリン)，セロサイジン，フェナ ジン，カルボキシンなどの作用機構が詳しく研究されて いる. 生化学におけるエネルギー代謝系の研究は 20 年 前には盛んに行なわれ，多くの技術に関する解説書，総 説書が出版され，これらの成書を参照されたい，主たる 代謝経路について，上記の薬剤の実験例， TCA 回路に セロサイジン1)，電子伝達系にアンチマイシン $\mathrm{A}^{2,3)}$ ，力 ルボキシン4), Uncoupler にフェナジン5), オリゴマイシ ン6)などの報告をモデルにして行なうと便利である.

2）蛋白合成阻害剂

蛋白合成系に作用する化合物の研究は，1950年の後半 から盛んになり，多くの抗生物質は蛋白合成阻害剂とし て知られている. 数多くの研究報告の大半は大腸菌を用 い，無細胞系は Nirenberg (1961) の実験系に準じて行な われている7.

蛋白合成系の反応系で必要因子として

i）蛋白合成の場でありリボゾーム：一般には， $15,000 \times g$ 冷却遠心での上澄から, $105,000 \times g$ の沈澱区 分を取って用いている。

ii） $m$ RNA：一般に，合成された polynucleotide あ るいはファージ，ウイルスなどの RNAを用いる。

iii）アミノアシル RNA：一般に，超遠心 105,000× $g$ の上澄に存在する.

iv）エネルギー生産系：たとえば，phosphoenolpyruvate に pyruvate kinase を加える.

v） $\mathrm{Mg}^{++}$：適当量存在しないと，ポリゾームの形成， $70 \mathrm{~S}$ リ゙ゾーム $\underset{\mathrm{Mg}^{++} 10^{2} \mathrm{M}}{\stackrel{\mathrm{Mg}^{++} 10^{-4} \mathrm{M}}{\longrightarrow}} 50 \mathrm{~S}$ サブユニット+ $30 \mathrm{~S}$ サブユニットの調節が悪くなる.

vi） $\mathrm{K}^{+}$あるいは $\mathrm{NH}_{4}+$.

vii) Initiators である $F_{1}, F_{2}, F_{3}$, Elongation factors $\mathrm{Tu}, \mathrm{Ts}, \mathrm{G}$, 解離因子 $\mathrm{R}_{1}, \mathrm{R}_{2}$ など.

viii）その他， $\mathrm{K}^{+}$イオンあるいは $\mathrm{NH}_{4}{ }^{+}$イオン，メル カプトエタノール，などがあげられる。

しかしながら，蛋白合成系をはじめられる研究者には， 上記の必要因子を念頭に入れて，完全菌体から各段階の 無細胞系でア之ノ酸の蛋白分画への取りこみ実験を勧め たい，一般に，無細胞系としては，菌体懸濁液を超音波， フレンチプレス，海砂などで細胞をできうる限り，リボ ゾームに損傷を与えないように破壊し，低速遠心で未破 壊細胞や細胞破片を除去し，超遠心 $30,000 \times g 30$ 分間 の上澄をS 30 区分として実験に供している。詳しいこ とは Nirenberg, M. W. (1963) の実験方法を参照された 
い、なお，蛋白合成の実験で最も重要な過程は，アそノ アシル $t$ RNA のリボゾームへの結合, ペプチドの転移 反応，転位反応拈よび終了反応である.

i）アミノアシル $t$ RNA のリボゾームへの結合： GTP と Tu 因子の結合体はニトロセルローズ・フィルタ 一に吸着するが，この結合体にアミノアシル $t$ RNAを 加えてできた複合体はフィルターを通過するようにな り，この結合反応は容易に測定できる ${ }^{8)}$.

ii）ペプチド転移反応：リボゾームの Donor site に 結合しているぺプチジル $t$ RNA と Acceptor site に結合 しているアミノアシル $t$ RNA がペプチド結合する反応 で，ピュロマイシンを作用させることによって，ピュロ マイシンとペプチジル $t$ RNA が反応し, ペプチジルピ ュロマイシンを生じ, リボゾームから遊離する。この反 応をピュロマイシン反応と称し, ペプチド転移反応の測 定に用いられている99.

iii）ペプチド転位反応：この反応はペプチジル $t$ RNA がリボゾームの Acceptor site から Donor site に 転位する反応で, $m$ RNA の送りがあり, 新しいコード ンが A 位に展開する。この反応はピュロマイシン反応の 応用で，ペプチジル $t$ RNA が Acceptor site から Donor site に転移した分だけピュロマイシンとの反応性が増え ることによって転位反応を測定する方法である。ほか に，トリペプチド以上のペプチド合成を段階的に測定す る方法もある ${ }^{10)}$.

iv）蛋白合成終了反応の測定法：蛋白合成が進行し ている際に, Acceptor site に $m$ RNA の UAA, UAG などナンセンスコードンが現われると蛋白合成が終了 し，ペプチドがリボゾームから離脱する．この反応の測 定には, Capecchi の方法 ${ }^{11)}$ と Caskeyの方法 ${ }^{12)}$ が用いら れている．前者はやや複雑であるが，正確性が高い。

前述のとおり，蛋白合成系には多くの因子が関与して いる. たと光ば, 開始因子 ${ }^{13,14)}$, 伸長因子 ${ }^{15)}$, 解離因子 ${ }^{11)}$ などがある.これらはいずれも生体から抽出精製して反 応系に加えて実験が行なわれている。 それらの取り方に ついてはおのおの報告を参照されたい。

糸状菌をはじめ各種真菌類を用いた実験系は少ない。 医薬関係では Candida 属菌, 農薬関係では Pyricularia oryzae ${ }^{16)}$, Pellicularia sasakii ${ }^{17)}$, Sclerotium batalicola ${ }^{18)}$ を用いた実験例があるが，いずれも粗汁液を用い て，上記の実験系に準じて行なっている.しかしながら， 真菌を用いて蛋白合成の実験を行なう場合，下記の点に ついて，とくに注意すべきである。

（1) 供試菌体は胞子懸濁液を $24 \sim 48$ 時間均一に発芽 生育したものを用いる.
(2) 細胞破壊には通常フレンチプレスを用いるが，加 圧時にはできうる限り低い圧力で小刻みに行ない，リボ ゾームの損傷を少なくする.

(3) 用いる緩衡液は通常トリス塩酸 $10^{-2} \mathrm{M}$ 緩衡液であ り, 細胞破壊時には $\mathrm{pH}$ が若干低下するので, 微アルカ リ性にする. $\mathrm{Mg}^{++}$イオンは $10^{-2}$ モルを用いる.

その他，細かい操作は報文を参照されたい。

なお，高等植物の実験系については省略させていただ きたい。

3）細胞壁合成阻害剤

細菌の細胞壁は主として，多糖体ペプチドグリカンか らなっていて，その構造および生合成の研究はペニシリ ンの作用機構の研究に伴って著しく進歩し, その報告お よび総説はかなりの数になる，本文では細菌の細胞壁合 成阻害剤についての研究技法を割愛し，糸状菌とくにポ リオキシンについて述べたい。

農業用抗生物質の作用点として, 糸状菌の細胞壁中の キチン合成を特異的に阻害することを見つけた最初の七 ントは光学顕微鏡下において，ポリオキシン処理菌体の 菌系先端が異常に膨潤 (swelling) することからである ${ }^{19}$. 糸状菌は一部の種類を除いて, 細胞壁にキチンを主成分 としている。キチンはグルコサミンのポリマーで，グリ コサそンのラベル体を用いて取りこみ実験を行なえば， 普通の条件下で容易に細胞内に取りこまれる。佐々木ら （1968）によれば，50\%エタノール $0^{\circ} \mathrm{C}$ で反応を停止し た後, $1 N \mathrm{KOH}$ および $1 N \mathrm{HCl}$ で洗浄した塩酸水溶 液不溶区分を $2 \mathrm{~N} \mathrm{HCl}$ で 6 時間加水分解した可溶区分 にポリオキシンの影響が少なく，その不溶区分をさらに $6 \mathrm{~N} \mathrm{HCl}$ で 6 時間加水分解した可溶区分に著しい影響 が認められた。このことから，実験を進めるに当たっ て，各段階における影響の検討が必要である ${ }^{20)}$. 次に研 究で必要な過程として，無細胞系あるいは䣼素系を用い て証明することは必然的である。そこで, 遠藤ら (1969) は Glaser et al. (1957) の方法に準じて，Neurospora crassa からキチンシンセターゼを調整し，ポリオキシン D の作用点を立証した ${ }^{21)}$. 同様の方法で太田ら (1970) はイネいもち病菌体から同様の酵素を得ることができ た ${ }^{22)}$. これらの実験系を用い，而性菌機構の解明など詳 しく行なわれてきた。

4）ステロール生合成阻害剂

これまで農業用殺菌剤が脂質合成，とくにステロール 系物質の生合成を阻害することはあまり研究されていな かったが，近年，麦，果樹，蔬菜類のうどんこ病に特異 的に防除效果を示すいくつかの物質がエルゴステロール の生合成を阻害することが明らかにされてきだ2 ${ }^{23-31)}$ ，今 
後も同様の作用機構を有する殺菌剤が開発される可能性 も高いので，ここではエルゴステロール合成阻害剂を例 としてステロール生合成研究の技法について概説する。

i）適用する微生物

ステロール生合成を阻害する薬剤は糸状菌の分生胞子 の発牙よりも菌系の伸長を抑制し, 発芽管の異常分岐, 膨化といった形態異状が観察されることが特徴的である から, 薬物実験に先立って病原菌の植物体上での薬剂に よる影響をよく検討しておくことが肝要である.うどん こ病菌は絶対寄生菌であるので, 生化学的な薬理研究の 材料としては使用することがむずかしいため，その物質 に感受性で，しかも取り扱いがあまり困難でない他の微 生物を用いることが多い.たとえばトリアリモールの作 用機構の研究には主として Ustilago maydis(トウモロコ

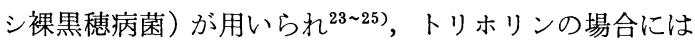
Neurospora crassa ${ }^{26)}$, Aspergillus fumigatus ${ }^{27)}$ が，ま たデンマートの場合には Monilinia fructigena (モニリ ア病菌 $)^{28 \sim 29)}$ ，Saccharomyces cerevisiae ${ }^{30)}$ が用いられ ている．動物の主要なステロールがコレステロールであ るのに対し，系状菌や酵母では炭素原子を 1 個多くもつ エルゴステロールであるが，生合成経路のうち，アセチ ル CoA からラノステロール生成までの過程は, 両系で 同じとされている ${ }^{32,33)}$. 系状菌, 酵母相互間でもエルゴ

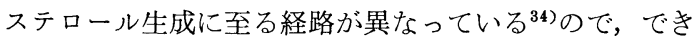
れば両者を用いることが望ましい.

微生物の培養については個々の場合で異なるから割愛 するが，とくに無細胞系で実験を行なおうとする場合 は，活性が培養条件によって非常に影響を受けやすいの

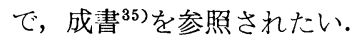

ii）標織化合物の取込久と脂質の抽出

ステロールの炭素原子のうち，24位のメチルあるいは エチル基はメチオニンに由来するが他はすべて酢酸より メバロン酸を経てその骨格が形成される. 生菌の場合, メバロン酸は膜の透過性が覀いので通常 ${ }^{14} C$-酢酸が用い られる．以下に加藤らの実験例 ${ }^{29)}$ を紹介する.

Vogel 培地 $\mathrm{N}$ に酵母エキス等を加えた培地で, $28^{\circ} \mathrm{C}$, 18 時間振燙した Monilinia fructigena の菌糸懸濁液を $25 \mathrm{ml}$ の三角フラスコに $1.5 \mathrm{ml}$ 分取し, 薬液を添加して $28^{\circ} \mathrm{C}, 1$ 時間前振りする（薬液溶媒のメタノールは $1 \%$ を越えないようにする). ${ }^{14} C(\mathrm{U})$-Sodium acetate に 1.0 $\mu \mathrm{C}$ 加えて反応を開始し, 振蕰培養を続ける. 経時的に メタノールークロロホルム $(2: 1, \mathrm{v} / \mathrm{v})$ を加えることによ り反応を停止させる.

脂質の抽出には Folch の分配法 ${ }^{36)}$, Bligh-Dyer の方 法 $^{37)}$ とその変法 ${ }^{38 \sim 40)}$ など種々の方法が用いられる. Sis- ler らは, 反応を終った菌体を蒸留水で洗滌し, 凍結乾 燥した菌体に Folch らの方法を適用している23 27) が， 他の方法では湿菌体から脂質を抽出している. 以下に微 生物からの総脂質の抽出例 ${ }^{40)}$ を示す.

菌体を緩衝液で洗滌後，1溶の水に懸濁し， 2.5 溶の メタノール，1.25溶のクロロホルムをこの順序に加えて そキサーでよく攪汼する．室温に約 10 分間放置後, 1.25 $\mathrm{ml}$ のクロロホルムを加えて再びはげしく振蕰し, さら に $1.25 \mathrm{ml}$ の水を加えて攪挥する. ついで 2,000 3,000 rpm，5分間の遠心を行い，下層（クロロホルム層）を注 意して回収する．脂質の回収力を良くするために，さら に $1 \mathrm{ml}$ のクロロホルムを加えて抽出をくり返寸. 得ら れたクロロホルム画分を合わせ， $35^{\circ} \mathrm{C}$ 以下で減圧濃縮 する.

iii）脂質の分画

総脂質から単純脂質 (中性脂質 : 遊離脂肪酸とそのグ リセリド，ステロールを含む）と複合脂質（極性脂質 : 燐脂質を含む）への分離は，燐脂質が冷アセトンに難溶 であることを利用して行なうことができる．複合脂質 は，小量のクロロホルム脂質分画を大量のアセトンを注 いだ後遠心沈搌させる ${ }^{29)}$ か，フリーザー $\left(-20^{\circ} \mathrm{C}\right)$ に一 夜放置して沈澱させる ${ }^{24)}$. 上澄を濃縮乾涸した後，アセ トンーエタノール（容量比 $1: 1 ）$ に溶解して，0.5 1\% ジ ギトニン $(50 \%$ エタノール溶液) を等量加えて 1 2 日 間冷蔵庫に保存するとステロールはジギトニン付加物と して沈澱する41). 沈澱を遠心して集め，アセトンで洗涤 した後，ジメチルスルホキシド中で付加物を分解し（沸 騰湯浴上, 15 分)，n-ヘキサンで遊離したステロールを 抽出する ${ }^{42)}$.

また，より直接的にステロールを抽出する方法として アセトンで抽出する方法 ${ }^{43)}$ や $\mathrm{KOH}$-エタノールでけん 化を行なってから石油エーテルで抽出する方法 ${ }^{30)}$, トリ クロロ酢酸で沈澱させ, 沈澱部をメジチルスルホキシド で処理した後, 石油エーテルで抽出する方法 ${ }^{41) な と ゙ か ゙ あ ~}$ る.

総脂質はまた，直接に薄層クロマト $(t l c)$ 上で分画す ることができる. Sherald と Sisler ${ }^{27)}$ は, Adsorbosil-1 シリカゲル (Applied Science Lab.) を用いてへキサンー ジェルチルエーテル-酶酸（容量比 80:20:1）の系で $t l c$ を行ない，燐脂質(原点)，4-デスメチルステロール，4メチルあるいは 4,4-ジメチルステロール, 遊離脂肪酸, トリグリセリド，ステロールエステルを分離している. またシリカゲル $60 \mathrm{~F}_{254}$ をプリコートした $t l c$ 薄粕板 (Merk) を用いてヘプタンーイソプロピルエーテル-酢酸 （容量比 60:40:4）で展開すると, 原点に複合脂質, $R f$ 
$0.11 ， 0.14 ， 0.20 ， 0.23 ， 0.50,0.65$ にそれぞれジグリセ リド，4-デスメチルステロール（エルゴステロールを含 む)，4- $\alpha$ メルステロール，4,4-ジメチルステロール， トリグリセリド，ステロールエステルが分離される ${ }^{28)}$. スポットの検出には，25〜 50\%硫酸を噴霧する方法 ${ }^{44)}$ よく用いられるが，スポットのかきとり定量用には，ヨ ウ素蒸気にさらしたり ${ }^{45)}, 0.02 \% 2^{\prime}, 7^{\prime}$-ジクロロフルオ レセインをスプレイする方法が用いられる.

ステロール分画の分離同定，定量にガスクロマトグラ フィーが偉力を発揮することはいうまでもないが，その 詳しい使用法については成書 ${ }^{46)}$ を参照されたい，加藤 $ら^{29)}$ は, 島津 4BM 型 (FID 付) で, $1.0 \mathrm{~m} \times 30 \mathrm{~mm}$ の力 ラムに Chromosorb W $(60 \sim 80$ メッシュ)に $3 \%$ SE 30 を吸着させたものを充てんし，カラム温度 $260^{\circ} \mathrm{C}, \mathrm{He}$ 流 速 $60 \mathrm{ml} /$ 分の条件で分析している.コレステロールが標 品に含まれていない場合には，内部標準として使用する と便利である.

物質の完全な同定や構造決定には，GC-MS, NMR の 併用，ラジオガスクロの応用などが必要となるが，薬理 研究の初段階では必須でないと思われるので，ここでは 省略する．また無細胞抽出液での実験系については，文 献 ${ }^{30,41)}$ および成書 ${ }^{35)}$ を参考にされたい。

以上各代謝系を作用する防除薬剂を実例としてあげた が，核酸合成阻害剤についてはその例は少なく，紙数の 関係で省略させていただいた。

\section{II. 殺菌剤の薬理研究と代謝分解}

前述のとおり植物病害防除剂の多〈は，直接殺菌作用 あるいは少なくとも病原菌の生育抑制力を有している が，なかには in vitroでは病原菌に対してほとんど阻止 効果を示さないのに，宿主植物体上 (in vivo) では顕著 に病害を抑えるものがある，その要因にはいろいろあろ うが，大別すると以下のことが考えられる。

イ）薬剤の面から：薬剤が，作用点に到達するまで に，(とくに植物体中で)代謝を受け，強い抗菌力をもつ 代謝物に変換されるか，植物体成分と共存してはじめて 抗菌力を示す.

口）病原菌の面から：病原菌が感染するのに必要な 過程（たとえばセルラーゼ，ペクチナーゼ等の酵素活性 あるいはその生成）を特異的に阻害するか，病徴の発現 に関与する病原体の二次代謝(たとえば発病毒素の生成) を阻害，または毒素を不活化する。

八）宿主の面から：植物に作用して宿主抵抗性を増 強する.

病害防除の効果発現に植物が関与し，複雑な感染過程
のいずれかを特異的に阻害するような薬剤は，直接生理 作用の強いものにくらべて安全性の面から危険性が少な いといえよう。したがって今後開発される薬剤には，こ のようなタイプの化合物が增えることが予想されるが， それらの薬理機構は，これまで他の薬剤に用いられてき た技法をそのまま適用しただけでは解明されないであろ う. 寸なわち単に生化学的な方法のみならず，代謝分解 や植物病理学的な研究とのコンビネーションが必須とな ると思われる.ここではこれまで開発実用化されている 病害防除剂には，このような見方に立って十分に薬理機 構が解明された例もほとんどないことから，関連した研 究の例を概説して, 将来の研究の参考に供することにす る.

1) ベノミルとチオファネートメチル

代表的なベンズイミダゾール系殺菌剤であるべノミル は,植物体内に速やかに浸透して強い抗菌力を示す47 49). ベノミルはそのものが広い抗菌スペクトルを有している が，植物体内では効率良く殺菌性のある安定な代謝物 $\mathrm{MBC}$ (メチル-2-ベンズイミタゾールカーバメート:カー ベンダジン）に変換され，植物体中で実際に移行してい るのは大部分 $\mathrm{MBC}$ で殺菌作用にも大きく寄与している と考えられている50,51). チオファネートメチルは, いも ち，炭疽，紋枯病に in vivo で有効で in vitro では効 果を示さない ${ }^{52)}$ が，それはべノそルと同様に宿主体内で $\mathrm{MBC}$ に変換される ${ }^{53,54)}$ ためである. $\mathrm{MBC}$ は微小管蛋 白質と結合することにより紡錘体の形成を阻害して，有 糸核分裂を妨げる ${ }^{55 \sim 57)}$. しかしべノミルとチオファネー トメチルは，比較的高濃度では，MBC による有糸核分 裂阻害作用のほかに，MBC にはあまりみられない呼吸 阻害もあわせて発現する ${ }^{56,58)}$ 。このことは，種々の代謝 反応が必ずしもすべて解毒反応でないばかりか，活性化 でありうることと, 直接殺菌力の強い薬剤といえども， とくに植物体中で速やかに代謝されるような場合には， 実際にはその代謝物が病害防除剤として作用している可 能性のあることを暗示している.したがって直接殺菌力 の強い薬剤に対して in vitroで得られた作用機作が副次 的な効果を調べたものに過ぎない場合もありえるわけで ある・

2) ペンタロルベンジンアルコール $(\mathrm{PCBA})$

水銀剂に代わる抗いもち剂として開発された PCBA は，堆肥中で生成する代謝物 ${ }^{59)}(2,3,5,6$-テトラクロル 安息香酸，2，3，6-トリクロル安息香酸等）のウリ類に対 する強い薬害のためにその後の使用はされなかったが， いもち病菌に対してほとんど抗菌力を示さず，侵入菌系 がイネ体内に侵入する過程を特異的に阻害する ${ }^{60)}$ という 
点で作用機構の面から興味深い化合物である．奥と角 ${ }^{61)}$ は，その機構を解析するためにセロファン穿孔法を考案 し，PCBAが宿主を介した 2 次元的作用ではなく，直接 いもち菌に作用して病原性(侵入力)を失わしめることを 明らかにした。しかしなぜ病原性が失われるかについて その後の追及は十分行なわれていない。

3）オリゼメート

オリゼメート（プロペナゾール）もいもち病防除薬剤 であるが，抗菌力はあまり強くないにもかかわらず，葉 鞘検定を行なうと低濃度 $(10 \mathrm{ppm})$ で菌のイネ体内への

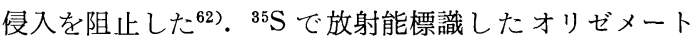
を根部処理すると,放射能は上方移行して葉部に集積し， オリゼメートは代謝されてサッカリン， N-D-グルコピ ラノシルサッカリンを生成した ${ }^{63)}$ 。これらの代謝物が菌 の侵入阻止に作用していると考えられるが，その機構の 詳細はやはり不明である.

4) イソプロチオラン

イソプロチオランは，いもち菌の菌糸の生育も阻害す るが(形態異状)，他の過程にくらべて侵入および侵入菌 糸の生育を強く阻害した ${ }^{64)}$. この実験では，染色を用い たセロファン穿孔法が用いられている，侵入部位は，お そらく酵素によるセロファンの変性で, 顕微鏡下染色さ れずに halo を形成する64).

5）トリサイクラゾール

トリサイクラゾール (EL 291) もイネいもち病の防除 に顕著な効果を示すが，in vitro での活性はきわめて弱 ( $^{65)}$. Tokousbalides と Sisler ${ }^{66)}$ は, いもち菌の生産す る毒素 pyricurol の生成を調べたが，何ら阻害は認めら れず,メラニン色素の生成に至る他のポリケタイド代謝 が著しく阻害されることを見いだした，彼らはこのポリ ケタイド代謝が病原性に関与していると推定している が，薬理機構の十分な解明にはまだ至っていない.

以上述べたほかに宿主植物の抵抗性増強と病原性の不 活化については成書 ${ }^{67)}$ に詳しいので参照されたい。

\section{おわりに}

以上農薬として特色をもった殺菌剂についての研究技 法を重点に紹介したが，実用化されている農業用殺菌剤 に限っていえることは同一作用点をもつ異なった薬剤の ないことである.したがって, 今後, 薬理研究を進める に当たって，上述の技法で大筋の作用性は求められても， 細かい作用点は研究の進行過程における各段階の細かい 現象を見逃がすことなく，創意工夫を活かして行なうこ とが肝要である.まして, 最近の病害防除薬剤の多くは 生体上に散布してはじめて薬剤効果を示すことから，植
物体を用いた薬剤，病原菌および宿主三者を用いた総合 実験系で研究を進めなければならない。この点から考 光，薬理研究は新しい転換期を迎え，われわれ関係研究 者の研究意欲を一首舊起させるものである.

\section{引用 文 献}

1）沖本陽一郎・見里朝正：日植病報 28, 250 (1963)

2) V. R. Potter \& A. E. Reif: J. Biol. Chem. 194, 287 (1952)

3）原田雄二郎・熊部 潔 - 香川恒雄 - 佐藤庸夫：日 植病報 24，255（1959）

4) D. E. Manthre: Phytopathology 60, 671 (1970)

5) 関沢泰治：日植病学会病理化学談話会 pp. 79 98, 1969

6) H. A. Lardy, J. L. Connelly \& D. Johnson: Biochemistry 3, 1961 (1964)

7) M. W. Nirenberg: Methods of Enzymology 6, 17 (1963)

8) J. M. Ravel, R. L. Shorey \& N. Shive: Biochem. Biophys. Res. Comm. 29, 68 (1967)

9) M. Hierowski: Proc. Natl. Acad. Sci. 53, 594 (1965)

10) A. L. Haenni \& J. Lucas-Lenard: ibid. 61, 1363 (1968)

11) M. R. Cappecci: ibid. 58, 114 (1967)

12) C. T. Caskey, R. Tompkins, E. Scolmick, T. Caryk \& M. Nirenberg: Science 162, 135 (1968)

13) D. A. Shafritz, D. G. Laycock \& W. F. Anderson: Proc. Natl. Acad. Sci. 68, 496 (1971)

14) D. A. Shafritz \& W. F. Anderson: J. Biol. Chem. 245, 5553 (1970)

15) D. A. Shafritz \& W. F. Anderson: Nature, 227, 918 (1970)

16) K. T. Huang, T. Misato \& H. Asuyama: J. Antibiotics, Ser. A 17, 65 (1964)

17) K. T. Huang, T. Misato \& H. Asuyama: ibid. 17, 71 (1964)

18) T. J. Obrig, Jana Cerna \& D. Gottlieb: Phytopathol. 59, 187 (1969)

19）江口 潤・赤柴健夫 ·佐々木茂樹 ·上山啓夫 · 鈴 木三郎：日植病報 32，99（1966）

20）佐々木茂樹・太田農夫也・山口 勇 - 黒田 節 · 見 里朝正：農化 42，633（1968）

21) A. Endo, K. Kakiki \& T. Misato: J. Bacteriol. 104, 189 (1970)

22) N. Ohta, K. Kakiki \& T. Misato: Agric. Biol. Chem. 34, 1224 (1968)

23) N. N. Ragsdale \& H. D. Sisler: Biochem. Biophys. Res. Comm. 46, 2048 (1972)

24) N. N. Ragsdale \& H. D. Sisler: Pestic. Biochem. Physiol. 3, 20 (1973)

25) N. N. Ragsdale: Biochem. Biophys. Acta 380, 81 (1975)

26) J. L. Sherald and, N. N. Ragsdale \& H. D. Sisler: 
Pestic. Sci. 4, 719 (1973)

27) J. L. Sherald and H. D. Sisler: Pestic. Biochem. Physiol. 5, 477 (1975)

28) T. Kato, S. Tanaka, M. Ueda \& Y. Kawase: Agric. Biol. Chem. 38, 2377 (1974)

29) T. Kato, S. Tanaka, M. Ueda \& Y. Kawase: ibid. 39, 169 (1975)

30) T. Kato \& Y. Kawase: ibid. 40, 2379 (1976)

31) P. Leroux \& M. Gredt: Phytopath. Z. 86, 276 (1976)

32) G. Popják: "Proceeding of the International Congress of Biochemistry", ed. by G. Popják, Pergamon Press, Oxford, Vol. 7, p. 207, 1963.

33) H. Rudney: ibid. Vol. 7, p. 254, 1963

34）加藤寿郎： “農薬”（山本 出, 深見順一編） ソ フトサイエンス社, p. 191（1979）

35）香月裕彦：“生化学実験講座 9”（日本生化学会 編）東京化学同人, p. 142 (1975)

36) J. Folch, M. Lees \& G. H. Sloane-Stanley: $J$. Biol. Chem. 226, 497 (1957)

37) E. G. Bligh \& W. J. Dyer: Can. J. Biochem. Physiol. 37, 911 (1959)

38) K. H. Yung \& J. B. Mudd: Plant Physiol. 41, 506 (1966)

39) M. Kates: "Techniques of Lipidology", North Holland Publishing Co., Amsterdam, p. 351, 1972

40）赤松 稉：化学と生物 10, 672（1972）

41) D. A. Monner \& L. W. Parks: Anal. Biochem. 25, 61 (1968)

42) C. H. Issidorides, I. Kitagawa \& E. Mosettig: $J$. Org. Chem. 27, 4693 (1962)

43）竹内 茂・河村 悟- 永井 純-香月裕彦：生化 学 46, 694 (1974)

44) O. S. Privett \& M. L. Blank: J. Am. Oil Chem. Soc. 39, 520 (1962)

45) P. P. A. Sims \& J. A. G. Larose: ibid. 39, 232 (1962)

46）植田伸夫：“生化学実験講座 3”（日本生化学会 編）東京化学同人, p. 61 (1975)

47) G. P. Clemons \& H. D. Sisler: Phytopathology 59, 705 (1969)

48) L. V. Edgington, K. L. Khew \& G. L. Barron: ibid. 61, 421 (1971)

49) G. J. Bollen: Neth. J. Plant Pathol. 78, 55 (1972)

50) C. A. Peterson \& L. V. Edgington: Phytopathology 61, 91 (1971)

51) G. P. Clemons \& H. D. Sisler: Pestic.Bio chem. Physiol. 1, 32 (1971)

52) T. Noguchi, K. Ohmura \& S. Kosaka: "Herbicides, Fungicides, Formulation Chemistry", ed. by A. S. Tahori, p. 263, 1972

53) Y. Soeda, S. Kosaka \& T. Noguchi: Agric. Biol. Chem. 36, 931 (1972)

54) A. Fuchs, D. L. Fernandez \& F. W. De Vries: Neth. J. Plant Patnol. 80, 7 (1974)

55) L. C. Davidse: "Microtubules and Microtubule Inhibitors", ed. by M. Borgers \& M. deBrabander, North-Holland publishing Co., Amsterdam, p. 483, 1975

56) R. S. Hammerschlag \& H. D. Sisler: Pestic. Biochem. Physiol. 3, 42 (1973)

57) D. V. Richmond \& A. Phillips: ibid. 5, 367 (1975)

58) J. R. Decallonne, M. Genot \& J. A. Meyer: Pestic. Sci. 6, 113 (1975)

59) M. Ishida: "Environmental Toxicology of Pestcides", ed. by F. Matsumura, G. M. Boush \& T. Misato, Academic Press, p. 281, 1972

60）角 博次 - 高日幸義 - 近藤泰彦：日植病報 $\mathbf{3 0}$, $112(1965)$

61） 奥 八郎・角 博次：日植病報 34, 250（1968）

62）渡辺哲郎 - 五十嵐 治 - 松本邦臣 - 関 誠夫 · 関沢 泰治：日植病報 37, 189 (1971)

63) M. Uchiyama, H. Abe, R. Sato, M. Shimura \& T. Watanabe: Agric. Biol. Chem. 37, 737 (1973)

64) F. Araki \& Y. Miyagi: Ann. Phytopathol. Soc. Jpn. 42, 401 (1976)

65) J. D. Froyd, C. J. Paget, L. R. Guse, B. A. Dreikorn \& J. L. Pafford: Phytopathol. 66, 1135 (1976)

66) M. C. Tokousbalides \& H. D. Sisler: Pestic. Biochem. Physiol. 8, 26 (1978)

67）奥 八郎：“農薬”（山本 出・深見順一編） ラ イフサイエンス社, p. 173 (1979) 